\title{
Hermenêuticas bíblicas para depois da V Conferência de Aparecida
}

\author{
Isidoro Mazzarolo
}

\section{Introdução}

A Igreja da América Latina e Caribe se prepara para um outro momento forte de reflexão sobre sua missão frente aos desafios próprios de seu contexto, com o lema: Discípulos e missionários de Jesus Cristo para que, Nele, os nossos povos tenham vida. Este lema suscita uma volta às fontes e um resgate dos princípios norteadores da Igreja da primeira hora, a fim de, que espelhados nela, os missionários/as de hoje, possam perceber o que pode ser feito melhor, o que pode ser aprimorado e o que ainda pode ser acrescentado, naquilo que já está sendo feito.

Em cada época e lugar, faz-se mister retornar às fontes e, nessa busca de fundamentação, "o que se exige da Igreja é que anime a comunidade humana, com a força perene e divina do Evangelho, num mundo que se gloria de seus progressos técnicos e cientificos, embora sofra de profunda carência ética, que procura sanar independentemente de Deus". ${ }^{1}$ O Espírito é o mesmo e so-

${ }^{1}$ JOÃO XXIII, Carta de Convocação para o Concílio Vaticano II, 25 de Dezembro de 1961. 
pra onde quer, esse Espírito que o mundo não pode conhecer (Jo 14,17). Sob a força e ação deste Espírito da Verdade, a Igreja recomeça, renova, retoma seu ponto de partida para atualizar e revigorar seu trabalho apostólico, catequético e querigmático. O grande trabalho do evangelizador é buscar, nas origens, o provável e o possível sentido da missão que Jesus quis passar aos discípulos.

Para encarnar melhor, na realidade atual, a mesma missão que Jesus confiou aos apóstolos, é imprescindível chegar ao sentido mais próximo das fontes, e, é preciso ir até elas e beber das mesmas, com o auxílio dos instrumentos e métodos das ciências bíblicas, históricas e sociais que o passado e o presente oferecem. Essa volta ao passado é um imperativo para as novas hermenêuticas e a confrontação com os novos paradigmas sempre em movimento e mudanças. ${ }^{2}$

Resgatar o passado é um debruçar-se sobre os desafios do futuro, porque as respostas dadas às questões do mundo de ontem não podem ser as mesmas oferecidas às interrogações do mundo de hoje, não obstante o ponto de partida para as interrogações e as respostas do ontem seja o mesmo para hoje e o amanhã. Assim, o retorno às fontes é uma exigência de cada tempo e momento. Beber das fontes é a certeza de beber água pura, água verdadeira e água viva (Jo 4,14).

A Igreja Latino Americana, hoje, se depara com novos imperativos pastorais e bíblicos, face a realidade sócio-política em que vivem seus habitantes, de modo especial, "ad intra", o discipulado e o apostolado. A Sagrada Escritura, que tanto tem iluminado e ajudado as comunidades nestes cinco séculos de presença, ${ }^{3}$ na formação de Comunidades Eclesiais, de Círculos Bíblicos, de grupos de leitura bíblica e investigação acadêmica, precisa ser "fonte e guia" nas mãos e na inteligência dos homens e das mulheres de boa vontade, a fim de revigorar o caráter missionário e evangelizador em prol das exigências hodiernas.

\footnotetext{
${ }^{2}$ ESTUDOS DA CNBB, 86, Crescer na leitura bíblica, 1.2; 1.3.

${ }^{3}$ Não fazemos, aqui, uma avaliação sobre os efeitos da colonização européia e seus métodos de avaliação e tratamento aos povos indígenas. É certo que, sob alguns aspectos, pairam muitas dúvidas em torno da eticidade da "descoberta" das Américas, mas não queremos entrar no mérito da análise do problema.
} 
Estaremos, neste artigo, propondo algumas considerações, sob o ponto de vista exegético e hermenêutico, considerando a realidade da América Latina, no que concerne à V Assembléia do seu episcopado, em Aparecida, 2007. Para tanto, tomamos, a nível de suporte, alguns textos bíblicos específicos.

\section{Tornar discípulas todas as nações, Mt 28,19}

Este é o primeiro texto que assumimos, neste quadro de "refontização" da mensagem bíblica, é o mandato final de Jesus aos discípulos, um mandamento pós-pascal, mas que ratifica e consolida toda a catequese repassada, nos tempos de sua presença física com eles.

Indo, tornai todas as nações discípulas, é um imperativo, não é um conselho ou uma opinião. Quando alguém dá um conselho, este pode ser levado a sério ou não, de acordo com o interesse de quem o recebeu. Um imperativo é uma ordem, mandamento e obrigação. No contexto do final do Evangelho de Mateus $(28,19)$, pós-ressurreição, Jesus pede, em caráter de mandamento, duas coisas aos discípulos:

a) Ir, sair, deslocar-se, ir ao encontro, ir para fora, perto ou longe, mas fazer um movimento vetorial centrípeto;

b) Tornar discípulas todas as nações, transformar, mudar, converter, reanimar as pessoas de todas as línguas, tribos, credos, confissões e convicções.

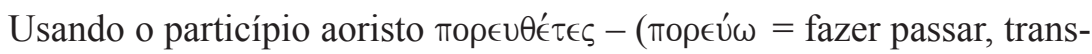
portar, partir para outro lugar, enviar, viajar $\left.{ }^{4}\right)$, "indo", partindo para fora, saindo, andando, se deslocando, visitando os lugares, aldeias e casas, em nome do envio (cf. Lc 9,2; 10,1 e par.). A missão não é uma espera, mas uma procura, não é um estar parado para o que vem, mas um ir ao encontro daquele(a) que não viria. A missão caracteriza a própria essência do apostolado, em vir-

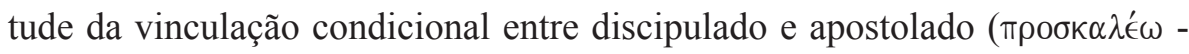

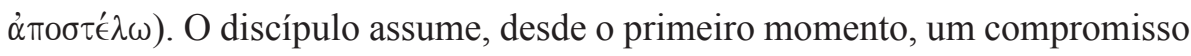

\footnotetext{
${ }^{4}$ BAUER, W., Wörterbuch zum Neun Testament, Berlin/New York, Walter de Gruyter, 1971.
} 
com aquele que o envia, e sua missão está voltada para o cumprimento de ordens e decisões superiores.

Essa ordem de Jesus faz eco nos dias de hoje, de modo especial no catolicismo, onde esse gesto de sair para buscar, de visitar cidades e aldeias, ir de casa em casa ou de leito em leito em hospitais parece ter perdido o sentido. As exigências são as mesmas: deixar o lugar geográfico e deslocar-se na direção do outro. Aquele/a que é enviado deixa sempre o lugar onde está na direção daquele para onde deve cumprir a tarefa. Partindo das vossas casas, deixando as vossas instalações, ide ao encontro dos outros, pelas ruas, praças, cidades e lugares próximos ou distantes, a fim de que lá também seja anunciado o Evangelho. Jesus dá seu próprio testemunho e exemplo, relatado nos Evangelhos: (tornando a entrar em Cafarnaum Mc 2,1; outra vez ao longo do mar Mc 2,13; entrou outra vez na sinagoga Mc 3,1; retirando-se com seus discípulos Mc 3,7, e assim por diante - de Nazaré para Cafarnaum, de lá por toda a Galiléia, depois a Samaria e, enfim, Jerusalém). Ele mesmo, como Mestre, esvazia de sua condição divina, a sua $\mu$ оффү̂ $\theta \in$ ô (forma de Deus, Fl 2,6) para ter uma comunhão maior com o povo das ruas, dos campos, das estradas e praças. A consciência da diaconia e do resgate, revela como Jesus faz de si oferta de redenção e libertação (Mc 10,45). Ele, Mestre e Senhor, assume o lugar do servo para ensinar a diaconia aos discípulos (Jô 13,1-15). No espírito da nova pedagogia da Salvação, sintetiza o Decálogo em Mandamento único, ao qual chama de Mandamento Novo: "que os ameis assim em vos amei" (Jô 13,34). Esse amor antropológico é também o amor a Deus, pois todo o caminho para Deus exige em caminhar para outro $=$ a antropologia da Salvação. Jesus ensina aos homens e mulheres, o caminho do amor, da solidariedade e da alteridade. ${ }^{5}$

Olhando para o exemplo dos primeiros cristãos percebemos que o discipulado e o apostolado caminhavam lado a lado, pois enquanto um grupo se ocupava da distribuição do pão, outro anunciava a palavra (At 6,1-7). O tempo

\footnotetext{
${ }^{5}$ Os movimentos de Jesus podem ser vistos, de modo muito didático, no Evangelho de Marcos, como descrição de pequenos movimentos. Do ponto de vista do deslocamento maior, podemos perceber mais em João e Lucas.
} 
do discipulado é necessário para o conhecimento, a assimilação e o aprimoramento, em seguida, vem a imperiosa tarefa do envio (Lc 9,1-6). De um lado está a ação de convocar, reunir e preparar; do outro, está a determinação de enviar. Essa estrutura conjunta é constitutiva do discipulado, visto que o discípulo não se prepara para si, para dentro, mas para fora e para os outros. Pode-se destacar o primeiro momento, se é que podemos separar o discipulado, enquanto uma seqüela Christi, com o intuito da preparação interior, e a segunda fase, o envio, como o tempo da ação. No entanto, uma está intimamente ligada com a outra e são quase indissociáveis. Se faltar o discipulado, ficará deficiente a missão e se não há missão, torna-se nulo o discipulado.

Ao cristão cabe uma consciência da essência de sua fé e relacionamento com seu Mestre: Para todos os efeitos, o discípulo só será discípulo enquanto estiver executando as ordens de quem o enviou: "Em verdade vos digo, não é o servo maior que o seu senhor, nem o apóstolo maior do que aquele que o enviou" (Jo 13,16; Lc 6,40).

O lexema $\mu \alpha \theta \eta \tau \in U^{\prime} \sigma \alpha \tau \epsilon$ indica uma ordem imperativa, uma exigência superior de fazer discípulos, tornar discípulos, conquistar para o Reino de Jesus Cristo, como seguidores do Mestre. O grego entende o verbo

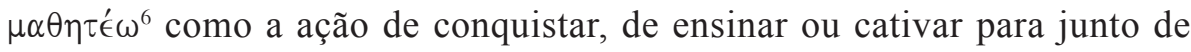
si. ${ }^{7}$ É uma relação entre um mestre e seus subalternos; do instrutor com seus aprendizes; um guia e seus liderados. É uma dimensão profissional e existencial que segue as características e coordenadas por Ele indicadas. $\mathrm{O}$ discípulo está sempre à escuta e ao entendimento da vontade de seu mestre, relação essa, que caracteriza todos os que se deixaram encantar ou que aceitaram o chamado do seguimento. O discipulado é caracterizado por uma formação de grupos ao redor de seus mestres: Heráclito, Platão, Aristóteles e outros no mundo grego tinham seus discípulos, suas escolas

\footnotetext{
${ }^{6}$ Enquanto o substantivo $\mu \alpha \theta \eta \tau \eta ́ s$ aparece 261 vezes no NT, o verbo encontra-se em Mt 13,52; 27,57; 28,19; Ap 14,21, cf. NEPPER-CHRISTENSEN, P., $\mu \alpha \theta \eta \tau \dot{s, ~ i n: ~ E x e-~}$ getisches Wörterbuch zum Neuen Testament, B, II, Stuttgart, Kohlhammer, 1981.

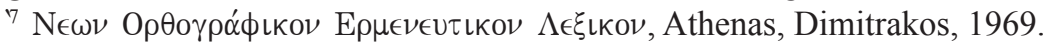


filosóficas e seus grupos. Paulo estava na escola de Gamaliel (At 22,3). Os essênios estavam agrupados ao redor do Mestre de Justiça. No contexto do NT, João Batista faz uma ponte entre os movimentos rabínicos e Jesus, também com seus discípulos; e Jesus, o mestre por excelência, forma um grupo de Doze (Lc 9,1ss) e depois outros setenta e dois (Lc 10,1ss) e assim, Ele quis que esse grupo conectasse o mundo dentro dessa mesma pedagogia e escola do amor. O discípulo se torna um mestre em relação ao mundo, mas será sempre discípulo em relação a Jesus. Por outro lado, toda a comunidade evangelizada, toda a pessoa evangelizada que um dia acolheu a Boa Nova do Reino, necessita desta consciência evangelizadora. ${ }^{8}$ Evangelizar é ser discípulo/a e apóstolo/a permanente e concomitantemente. Ser discípulo/a e apóstolo/a, no mundo atual é anunciar o Evangelho em quatro frentes:

a) Em primeiro lugar, a quem nunca ouviu falar dela;

b) Em segundo lugar, a quem ouviu e esqueceu;

c) Em terceiro lugar, a quem a pratica, mas de modo ainda insuficiente, ingênuo e pouco profético;

d) em quarto lugar, a quem a escuta, testemunha e pratica a fim de que seu discipulado seja cada vez mais profético e frutífero.

Desta forma, a ação evangelizadora não se esgota no momento em que a maioria das pessoas, ao redor de uma comunidade, já ouviu falar de Jesus, pois, muitos do que ouviram a Boa Nova, não a acolheram, outros já estão negligenciando sua prática e alguns não atualizaram seus conhecimentos (Mt 13,19-.18-23). A evangelização remete a um compromisso, a fim de que todos, possam estar convictos da responsabilidade de produzir frutos. Algumas vezes, a formação que esses cristãos possuem, é um conhecimento de algumas fórmulas, superficial e exterior igual a um verniz, e carece totalmente de profundidade, entendimento e profecia. ${ }^{9}$

Evangelizar é transformar, modificar, fazer novas as coisas antigas

${ }^{8}$ DOCUMENTOS DO VATICANO II, Evagelii Nuntiandi, n. 13.

${ }^{9}$ DOCUMENTOS DO VATICANO II, Evagelii Nuntiandi, n. 20. 
(2Cor 5,17; Ap 21,5). Se não há transformação não há Boa Nova, e para tanto é mister conhecer todas as formas de alcance da compreensão deste anúncio por parte das pessoas e povos. Essa transformação se processa, ao mesmo tempo, na consciência individual e coletiva dos homens e mulheres, na atividade que eles exercem e no meio em que eles se encontram. ${ }^{10}$

Fazer discípulos é cativar para junto de si, cativar para Cristo e seu seguimento, é convencer da validade, é promover o encantamento. O discipulado é deixar-se encantar, aceitar a provocação e entrar para a comunidade de fé com a consciência da missão. Ele parte do encantamento de quem nunca viu, e no momento que observa, fica extasiado e exclama: "Que é isso?" Um novo ensinamento com autoridade (Mc 1,27) ?! A evangelização pode ser um conteúdo antigo, primordial (1Jô 2,7) visto que é o mesmo Cristo que é anunciado, mas ele deve ser sempre novo, sempre atual, sempre surpreendente e convincente. Se o evangelizador não está convencido do que anuncia, não fará outro discípulo ou discípula.

No livro do Coélet (Eclesiastes 5,7), afirma-se que se numa Província for encontrado um mendigo, nela o direito e a justiça foram violados, e o injustiçado se transforma em sinal de enfermidade para essa cidade. Neste caso, o envio dos discípulos é para que curem todas as enfermidades e expulsem os demônios (Mc 3,13-15). Expulsar demônios não é fazer exorcismos, mas re-implantar a justiça e a verdade, libertando presos, curando os enfermos e anunciando a graça do Reinado de Deus (Lc 4,18-19). E, se todas as nações devem ser discípulas (Mt 28.19), em todas elas deve haver o mesmo projeto: curar seus enfermos, expulsar os demônios e anunciar um tempo de graça.

Todas as nações são todos os povos, línguas, raças e culturas. "Panta ethnê" significa o universo, a totalidade dos povos, a totalidade das pessoas, individual ou coletivamente. Cada povo, independente de sua história, passado ou tradições, tem o direito de ouvir, escutar, entender e optar a respeito do Evangelho. O reinado de Deus, da graça e da justiça, cabe em qualquer

${ }^{10} \mathrm{Cf}$. DOCUMENTOS DO VATICANO II, Evagelii Nuntiandi, n. 18. 
cultura, raça ou língua. Todas as nações merecem conhecer a novidade do Reino de Deus, independente de seu ponto de partida ou lugar determinado. $\mathrm{O}$ anúncio procede da autoridade que Jesus recebeu e que vai passar aos

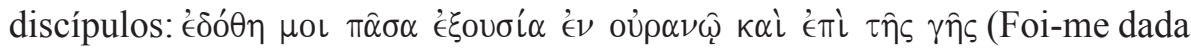
toda a autoridade, direito, liberdade de agir, poder para decidir, determinar e definir $^{11}$, no céu e sobre a terra - Mt 28,18). Quer nos céus, quer sobre a terra, o Reino se torna universal, sem fronteiras, sem limites geográficos, culturais ou ideológicos. A autoridade é também a credencial que os portadores desta missão recebem da parte de quem os envia. É uma autoridade que procede do alto, do Pai, e com isso, não há restrição de espaço ou lugar. E o que vem do alto atinge a totalidade, abarca o todo do cosmos.

Jesus assegura aos discípulos que sua autoridade é plena ( $\pi \hat{\alpha} \sigma \alpha)$, e eles não teriam o que temer, quanto à legitimidade do envio e da missão, mas poderiam ter suas garantias físicas ameaçadas, visto que eles estariam como cordeiros no meio de lobos (Lc 10,3). Eles poderiam ser perseguidos, caluniados e torturados por causa do Evangelho (Mt 5,11-12). A autoridade não era um salvoconduto contra os perigos e as ciladas dos opositores do Reino. A autoridade era, acima de tudo, a garantia de assistência do Espírito Santo (Jo 16,13).

As garantias da presença de Jesus, na missão (Mt 28,20), não são seguro de vida, imunidade diante do perigo ou garantias físicas. E, não obstante os riscos, eles são enviados, isto é, solicitados a deixar sua casa, pai, mãe e pertences, para ir ao encontro de quem está fora, numa certa desvantagem, pois são como cordeiros no meio de lobos (Lc 10,3). Ao entrar nas casas, os discípulos deveriam primeiro saudar os que lá estavam,dizendo que a paz estava chegando e o Reinado de Deus estava próximo (Mt 10,13; Lc 10,5). Evangelizar é ter a cara e a coragem de bater nas portas das casas, dos corações, das inteligências. É preciso "acordar", provocar, "vender" esse produto no qual se acredita. Esta ação exige uma mudança de lugar social e teológico. Sem um "sair" não acontece o imperativo de evangelizar "todas" as nações, o que também implica numa ação de resultados: enquanto

${ }^{11}$ BAUER, W., Wörterbuch zum Neun Testament, Berlin/New York, Walter de Gruyter, 1971. 
houver uma nação, um povo ou um indivíduo que não conheceu o Evangelho, os "Ministros" da evangelização estão em dívida com seu Senhor.

Fazer discípulos, num contexto de América Latina, é levar a sério o exemplo de Jesus que foi ao encontro dos homens e das mulheres de seu tempo. ${ }^{12}$ Esse exemplo pedagógico - das periferias para os grandes centros - e profético necessita de continuadores a fim de se "desencadeie um autêntico processo de conversão, comunhão e solidariedade". ${ }^{13} \mathrm{O}$ exemplo mais emblemático citado é o da conversão de Paulo, o qual, de perseguidor passa a evangelizador (At 9,3-30). No entanto, como nos tempos de Jesus houve convidados que resistiram, pois o convite pressupõe a liberdade, como o jovem rico (Mt 19,16-22 e par.), hoje, na América Latina, há muitos convidados que não aceitam assumir o desafio do Evangelho.

Alguns encontros com Jesus, referidos pelos Evangelhos, são claramente pessoais, resultantes de um trabalho "olho no olho", pessoa a pessoa, extremamente personalizados, como o chamado dos primeiros discípulos (Mt 4,19; 9,9). ${ }^{14}$ Esses receberam autoridade de Jesus (Mc 3,14-15) para que iniciassem, pela força do Espírito Santo (At 2,1-4), a transformação das sociedades. Esse processo transformador está testemunhado também na história destas Américas, com numerosos mártires, homens e mulheres, bispos e presbíteros, religiosos e leigos que com seu sangue banharam estas nações. ${ }^{15}$ Por outro lado, não faltaram e não faltam missionários receosos, tímidos e fracos na fé que ficam à espera do povo em suas Igrejas. Esses precisam ser re-motivados a encontrar o vigor da fé, a ousadia missionária da vocação e a coragem de proclamar a conversão. "A América necessita de cristãos leigos em grau de assumir cargos de dirigentes na sociedade. É urgente formar homens e mulheres capazes de influir, segundo a própria vocação, na vida pública, orientado-a para o bem comum. No exercício da política, considerada no seu sentido mais

\footnotetext{
12 JOÃO PAULO II, Ecclesia in America, 8.

${ }^{13}$ Ibidem.

${ }^{14}$ Idem, n. 9

${ }^{15}$ Idem, n. 15.
} 
nobre e autêntico de administração do bem comum, aqueles podem encontrar o caminho da própria santificação". ${ }^{16}$

O mandamento de Jesus aos discípulos, "ontem", continua válido, "agora", mais que nunca, num contexto tão complexo e descaracterizado, antropológica, política e eticamente. Fazer das Américas um Continente de discípulos e discípulas de Jesus significa ir ao encontro dessas multidões anunciando a justiça do Reino (Mt 5,20), com homens e mulheres conscientes do terreno onde estão semeando o Evangelho e responsáveis pela sementeira viva, ansiosa pela graça da Palavra e do testemunho. Por outro lado, no contexto do discipulado, faz-se necessário preparar evangelizadores com perspicácia diante das mais diferentes formas de ateísmo, de anti-cristianismo, de fabricantes da pobreza e da indigência de muitas comunidades excluídas do conhecimento, do saber e da dignidade do viver.

\section{Anunciar não é privilégio, é um compromisso 1Cor $\mathbf{9 , 1 6}$}

Paulo afirma: "Evangelizar não é objeto de jactância para mim, é, antes, necessidade que se me impõe - Ai de mim se eu não evangelizasse". O apóstolo fala de uma ação que já tinha acontecido: "evangelizasse", portanto, algo já em andamento, realizado, ou acontecendo, pois não estava concluído.

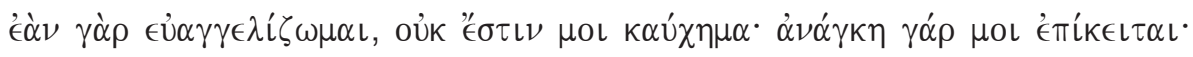

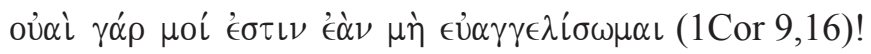

A ação de evangelizar, como uma relação com a divindade, é uma missão ligada à Transcendência, uma notícia da parte de Deus. ${ }^{17} \mathrm{O}$ mensageiro é, não raro, visto como um "anjo" de Deus, um embaixador dos céus, alguém que representa, que significa e que traduz uma mensagem do alto (cf. Ap 2,1; $2,8 ; 2,12 ; 2,18)$. A mensagem do Evangelho é algo que deve ser anunciada por força da incumbência recebida (Lc 9,6.20; Rm 15,20; Gl 1,11).

Evangelizar ( $\epsilon \dot{v} \alpha \gamma \gamma \in \lambda \hat{\zeta} \zeta \omega)$ é anunciar algo novo, diferente, melhor, e, do mesmo modo, cultivar, rever e confirmar o que foi anunciado, seguindo o

\footnotetext{
${ }^{16}$ Idem, n.44.

${ }^{17}$ BAUER, W., Wörterbuch zum Neuen Testament, Berlin, W. Gruyter, 1971.
} 
belo exemplo de Paulo, apóstolo dos gentios que não se cansava de voltar aos lugares onde havia anunciado o Evangelho, a fim de que os falsos pastores não semeassem a cizânia em seus campos de missão (At 15,36.41). Evangelizar é cativar para uma transformação. No saudosismo das tradições (representado no pai, mãe,... (Lc 14,26-27) há saudades, mas não novidades. O tradicionalismo é conservador porque, ao repetir o passado, impede que ele morra, se transforme e dê lugar ao novo. Evangelizar não é destruir o passado, mas atualizar a realidade cristã ou cada época, tempo, lugar (Mt 5,17). Jesus usou o recurso das coisas antigas e novas, como forma didática e pedagógica inerente ao processo da sabedoria da vida (Mt 13,52). Marcos descreve alguns detalhes da nova doutrina: Jesus, ao anoitecer, recebia a população inteira, curava todos os doentes, das mais diferentes enfermidades e expulsava demônios (Mc 1,36), curava leprosos (Mc 1,40-45), curava um paralítico em Cafarnaum (Mc 2,1-12), perdoava pecados (Mc 2,5), comia com pecadores (Mc 2,16) e diante do que via, o povo chegava a uma conclusão própria: Nunca vimos coisa semelhante (Mc 2,12)! E quando muitos queriam retê-lo, ele demonstrava com toda a firmeza a necessidade de ir para outros lugares, outras aldeias, pois lá também devia ser anunciado o Evangelho e era para isso que tinha saído do Pai e vindo ao mundo (Mc 1,38). Desta forma, $\epsilon \cup ̉ \alpha \gamma \gamma \in \lambda i \zeta \omega$ é tornar agradável, atraente e cativante uma proposta difícil, complicada e comprometedora. Esse encantamento é imprescindível para o êxito da mensagem, a qual só será Boa Nova se estiver revestida de graça e verdade $(\operatorname{Lc} 4,19)$. Sem encantamento não há aumento de discípulos e sem novos discípulos, a comunidade morre para Jesus Cristo (cf. Ap 3,1).

Evangelizar não é privilégio, orgulho ou ostentação (1Cor 9,16), visto que o missionário não pode fazer do seu lugar, do púlpito, do microfone ou de outro meio que esteja ao seu alcance, para promover-se a si próprio. O lexema "kauchêma" indica jactância e vanglória obtidas pela auto-promoção ${ }^{18}$. Este podia ser um dos problemas entre os pregadores de Corinto, denunciados

\footnotetext{
${ }^{18}$ BAUER, W., Wörterbuch zum Neun Testament, Berlin/New York, Walter de Gruyter, 1971
} 
pelos da casa de Cloé, a Paulo, e ele combate esse perigo (cf 1Cor 1-4). Não sendo questão de orgulho, será uma questão de ordem, de obediência, serviço

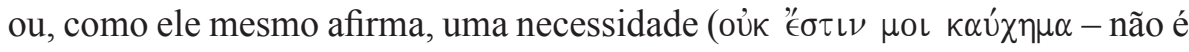

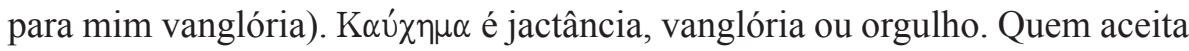
a missão da evangelização não pode palmilhar o caminho dos pagãos, dos oradores ou dos cínicos. É anunciar o caminho de Jesus e dar testemunho de modo radical. É bem verdade que há sempre uma possibilidade de falsos anunciadores, que se intrometem no serviço da missão, e querem anunciar por inveja ou rivalidade ( $\mathrm{Fl} 1,15)$, mas é por isso que Paulo faz esse apelo radical: Quem evangeliza, só evangeliza se promove e edifica profeticamente a comunidade (1Cor 14,1-4), e por isso, não há compatibilidade com a promoção pessoal, orgulho ou vanglória (1Cor 9,16).

$\mathrm{O}$ mandato de Jesus, de tornar as nações discípulas, compreende esse imperativo da transformação, pelo Evangelho, em nome de Jesus Cristo. Ainda que seja difícil e complexo estabelecer o sentido, o conteúdo e os modos da evangelização, tal como Jesus a concebia e a pôs em prática, é, no entanto, sempre possível entender alguns aspectos essenciais.

Um elemento, no entanto é claro, é mister encarnar o mandato de Jesus aos discípulos: "Andar de cidade em cidade a proclamar, sobretudo aos mais pobres, e muitas vezes os mais bem dispostos para o acolher, o alegre anúncio da realização das promessas e da aliança feitas por Deus, tal é a missão para a qual Jesus declara ter sido envido pelo Pai. E todos os aspectos do seu Ministério - a começar da própria encarnação, passando pelos milagres, pela doutrina, pela convocação dos discípulos e pela escolha e envio dos doze, pela cruz, até a ressurreição e à permanência da sua presença no meio dos seus - fazem parte da sua atividade evangelizadora". ${ }^{19}$

Evangelizar é ter autoridade sobre duas forças antagônicas ao Reino:

a) Os demônios;

b) As doenças $(\operatorname{Lc} 9,1)$;

${ }^{19} \mathrm{Cf}$. EN, 7. 
c) No exercício do poder do Espírito, faz-se mister ir de cidade em cidade anunciando a Boa Nova e fazendo curas por toda a parte" (Lc 9,6). Os demônios são todas as forças hostis ao projeto de Deus a respeito do ser humano (cf Jó 1,7; 2,1.4). Na narrativa de Mt 4,1-11, e ele se manifesta como o tentador, aquele que busca perverter as intenções mais íntegras e corretas . Na vida prática, os demônios podem ser conhecidos nos mecanismos da perversão, da corrupção e da morte (cf Lc 19,1-10). As doenças podem ter caráter diverso, físico, biológico, psicológico ou espiritual. O mandamento que Jesus dá a seus discípulos é que curem toda a espécie de enfermidade (Mt 10,1).

As curas são um sinal concreto e palpável do Reinado de Deus: "Em qualquer cidade onde entrardes e vos acolherem, comei o que vos oferecerem, curai os doentes que ali se encontrarem e anunciai: o Reino de Deus chegou até vós" (Lc 10,8-9)! Com certeza, ao falar de curar doentes, Jesus não entendeu que os discípulos substituiriam os médicos. Há muitas doenças que não precisam de remédios, mas precisam de oração, justiça, ética e fé, e estas os médicos não curam, só os discípulos. Há outras doenças que são causadas pelo pecado, perfídia, pela presença do espírito do demônio que gera ódio e violência, e essas são curadas pela conversão - essas também os médicos não curam. Há outras enfermidades causadas pela Mídia que são: a ganância do ter, poder e prazer, identificadas como lucro, moda, mercado, propaganda. Para libertar dessas enfermidades, só a força do Espírito.

Diante deste imperativo de transformação ética, política, sociológica, teológica e antropológica, tem sentido mais vivo a exclamação do

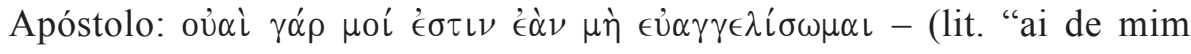
é, se não evangelizasse"). Se não tivesse evangelizado, o que teria feito de sua vida? O que poderia acontecer, caso não tivesse evangelizado? O verbo, no conjuntivo, revela uma ação já processada, mas que pode estar continuando, e isso traz a satisfação e ao mesmo tempo a constatação do bem e da missão, até aquele momento, cumprida. Seria o sal que perdeu o sabor ou o candelabro que se apagou (cf. Mt 5,13-16)? A conjunção con- 
dicional "se" coloca dois aspectos fundamentais para a compreensão da responsabilidade do evangelizador:

a) Num primeiro aspecto está posta a liberdade a todo aquele que é chamado, de tal forma que ele pode assumir ou pode não assumir a proposta;

b) Num segundo momento, depois de entender o chamado ele está comprometido com uma dimensão pré-estabelecida para a missão, diante da qual, já não cabem escolhas.

“Ai de mim, se não...” é o grito do evangelizador consciente, responsável, sábio e comprometido com todas as decorrências da missão. O discípulo sabe que foi chamado para anunciar e transformar, e caso não o faça, ai dele.

As doenças e os demônios não podem conviver ao redor dos discípulos. O Reino de Deus é Boa Notícia, isto é, o avanço do Bem e o recuo do Mal. "Como núcleo e centro da sua Boa Nova, Cristo anuncia a salvação, esse grande dom de Deus que é libertação de tudo aquilo que oprime o homem, e que é libertação, sobretudo do pecado e do maligno, na alegria de conhecer a Deus e de ser por ele conhecido, de o ver e de se entregar a ele". ${ }^{20}$

"Ai de mim se eu não evangelizasse" é um grito que ecoa ainda hoje, nas Igrejas, comunidades e povoados. Este grito não pode ser sufocado, abafado ou diminuído, nem mesmo desviado ou coagido a silenciar. Ele precisa ser tão forte e tão claro que possa ir além dos limites geográficos dos povos, e assim, ele possa transformar, pelo Evangelho, o critério de julgar, os valores que contam, os centros de interesse, as linhas de pensamento, as fontes inspiradoras e os modelos de vida da humanidade". ${ }^{21} \mathrm{O}$ batizado é um evangelizador por vocação. Ele precisa entender sua missão batismal e sua responsabilidade decorrente desta vocação. A consciência da novidade do Reino origina uma cadeia de atitudes de renovação, fazer as coisas serem sempre novas (Ap 21,5), tornar o homem velho uma nova criatura (2Cor 5,17; Gl 6,15).

O evangelizador é alguém que, antes de mais nada, precisa saber renunciar: pai, mãe, irmão e propriedades e assumir sua cruz (Lc 14,26-27).

\footnotetext{
${ }^{20}$ Cf. EN, 9.

${ }^{21} \mathrm{EN}, 19$.
} 
Renunciar ao pai, mãe e outras coisas anexas, significa deixar em segundo lugar as coisas que fizeram parte até o presente momento de sua história, pois de agora em diante, virá à missão. A missão exige sacrifício, doação e entrega, o que constitui a cruz de cada dia. A cruz pode ser o medo, o cansaço, o desencanto, as resistências das pessoas e lugares e todas as dificuldades inerentes à acolhida de uma proposta nova. O discípulo, que agora é um apóstolo, precisa ter clareza que assumiu um compromisso, uma responsabilidade e um acordo com Cristo. Não cabe ao evangelizador determinar o conteúdo, mas cabelhe, cumprir o que lhe foi pedido: "Assim como Tu me enviaste, eu também os enviei ao mundo" (Jo 17,18). Há uma relação intrínseca entre o envio do Filho e o envio do discípulo. A missão é a mesma, o Reino é o mesmo, apenas mudam os tempos e as formas de anúncio, a adequação da mensagem ao lugar e às culturas. Ao evangelizador cabe a consciência de que é um embaixador que executa ordens: "O servo não é maior do que o seu senhor, nem o enviado maior do que aquele que o enviou" (Jo 13,16). Esta relação transforma o missionário em um servo, alguém que está às ordens e não alguém que dá ordens. Ele só será servo enquanto estiver diretamente em contato com o seu senhor.

O apóstolo Paulo sente-se arrebato pela força do anúncio, e nesse arrebatamento vive uma comunhão forte com o Filho de Deus que o amou primeiro (Gl 2,20). Na perspectiva do Apóstolo, ele se tornou livre para assumir uma missão incondicional ao serviço das comunidades e das pessoas. Esse é um imperativo aceito, assumido e do qual já não pode abrir mão, visto que ele está ciente da grandeza da missão, da necessidade e da relação entre o anúncio do Reino e as condições de homens e mulheres esperando por ele. Dentro deste projeto, ele não pode vangloriar-se de sua missão e nem pretender recompensa. Ele não pode ser comparado a um trabalhador que escolhe uma profissão e fica esperando o pagamento correspondente. ${ }^{22}$

Diante deste paradigma emblemático que é a figura de Paulo, emergem alguns questionamentos para o processo de evangelização, hoje: Onde estão as

${ }^{22}$ BARBAGLIO, G. As cartas de Paulo I, São Paulo, Loyola, 1989, p. 283. 
figuras proféticas e apostólicas cujo carisma esteja tão patente e explícito? Onde estão àqueles homens e mulheres que aceitaram o chamado e, hoje, se sintam "seduzidos" pela força da missão? Onde estão os sinais dos profetas e profetizas que apontam com a vida e a palavra para o Evangelho e o Reino? Estaríamos diante de um silêncio profético, um tempo de escassez de consciências, inteligências e espíritos movidos pela diaconia à alteridade e ao Reino?

\section{Evangelizar para não esvaziar a cruz de Cristo, 1Cor 1,17}

O Vaticano II entendeu que havia lacunas entre o anúncio do Evangelho, em meados do século passado, e a sua proposta original, e por isso fez um caminho de refontização da fé e dos princípios a fim de que sua atualização se desse na justa medida dos tempos e momentos. "Por isso este Concílio, seguindo as pegadas dos concílios de Trento e do Vaticano I, quer propor a verdadeira doutrina da revelação divina e de sua transmissão, para que, ouvindo-a, todo mundo creia; acreditando, espere e, esperando, ame". ${ }^{23}$

A transmissão da revelação divina necessita seguir os passos originais, as pegadas primevas do cristianismo, sem pestanejar, mesmo que seja mister adequar aos lugares e às culturas todo o conteúdo e forma. O que está em questão, de modo primordial, é o vigor do amor pela vocação missionária e o ardor pela missão como consciência de uma diaconia pelo Reino. É o fervor inicial que necessita ser retomado, é o primeiro amor que precisa ser revigorado (cf. Ap 2,4).

No início da primeira Carta aos Coríntios, Paulo faz uma distinção entre batizar e evangelizar. Mesmo depois de vinte séculos, há muitas pessoas, que, não obstante engajadas, em meios pastorais e caminhos de formação cristã, não distinguem ou não conhecem as peculiaridades de cada uma destas funções. Qual seria a distinção pretendida pelo Apóstolo entre batizar e evangelizar? Já na tradição evangélica era feita uma distinção entre duas formas de batismo: água = João Batista; Espírito = Jesus (Mc 1,8; Jo 1,26.33; At 1,5;

${ }^{23} \mathrm{DV}, 1$, citando de modo livre St. AGOSTINHO, De catechizandis rudibus, 4,8. PL 40,316 . 
11,16). Apolo falava com intrepidez nas sinagogas a respeito de Jesus, mas só conhecia o batismo de João Batista (At 18,25). Priscila e Áquila, vendo seu fervor, ao refutar as más interpretações dos judeus a respeito das Escrituras, instruíram-no com exatidão sobre o Caminho (At 18,26). Com a chegada de Paulo a Éfeso, perguntou em qual dos batismos haviam sido batizados, e eles responderam: no de João. Assim Paulo, explicou aos cristãos de Éfeso, que o batismo de João era o do arrependimento, e depois, impondo-lhes as mãos, veio sobre eles o Espírito Santo (At 19,3-6). O batismo de João Batista representava algo bom, mas superado por Jesus, com o batismo do Espírito. A penitência é boa, mas tem que estar associada à profecia, à transformação e ao compromisso com Jesus Cristo.

Etimologicamente, $\beta \alpha \pi \tau i \zeta \omega$ significa mergulhar, afundar na água, imer-

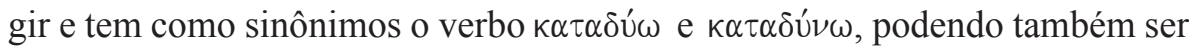
acrescidos os significados de revestir, vestir ou esconder. ${ }^{24} \mathrm{O}$ sentido semântico do mergulho, da imersão, do esconder nas profundezas das águas uma situação anterior, pode ter originado um sentido próprio na pedagogia de João Batista e depois dentro da Igreja. Ao emergir, fazia-se mister revestir a pessoa, dar-lhe outra veste seca e limpa.

Batizar é imergir, mergulhar, lavar, purificar ${ }^{25}$, e depois, teologicamente traduzido, significava abrir as portas para a fé, para o ingresso na comunidade e predispor para o recebimento do sinal de acesso, o sacramento. Evangelizar pode compreender também o batizar, mas é mais do que batizar. Quem batiza pode abrir as portas para o novo cristão, mas não comprometer-se com a caminhada e o desenvolvimento da fé. Na pedagogia de Paulo, encontramos um claro compromisso com todo o processo, desde a abertura para a opção com Cristo, até o desenvolvimento pleno e a maturidade do testemunho cris-

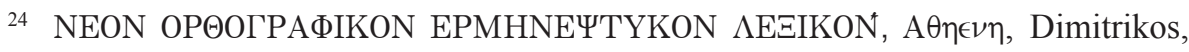
1969.

${ }^{25}$ BAUER, W., Wörterbuch zum Neun Testament, Berlin/New York, Walter de Gruyter, 1971; BONAZZI, B, Dicionario Greco-italiano, Napoli, Alberto Morano editore, 1943. 
tão. Ainda que Paulo não esteja fazendo uma "apologese", ele está colocando claramente uma distinção entre os dois passos. $\mathrm{O}$ evangelizador se compromete a conduzir o evangelizado ao compromisso sólido, radical e maduro da sua fé, a fim de que ele possa testemunhar, em qualquer circunstância a sua opção por Cristo e pelo próximo, sendo capaz de fazer de sua vida uma oferenda cultual ( $\mathrm{Rm} 12,1$ 2), na unidade máxima e total com o corpo de Cristo (1Cor 12). Como não podia haver dois batismos, Paulo está trabalhando para a superação de formas diferentes das que ele anunciara, e assim, chegar a uma unidade (cf. Gl 1,6-8; Ef 4,5-6).

Evangelizar é dar a alguém uma notícia agradável, anunciar um bom acontecimento, anunciar o Messias, a vinda do Filho de Deus ${ }^{26}$. Na encarnação desta missão, Paulo entende que evangelizar é profetizar, é edificar a assembléia, e construir comunidades libertas para Cristo e para uma nova concepção de sociedade (1Cor 14,1-19).

O discurso, sem o testemunho da ação, pode tornar vazia a cruz

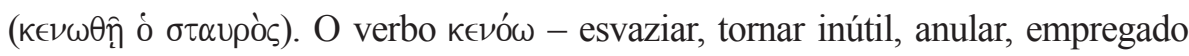
aqui na relação à cruz, está dentro de uma experiência existencial do Apóstolo. Ele sabe o que era ter corrido por causa do Evangelho: Dos judeus, recebi cinco vezes os quarenta golpes, menos um, três vezes flagelado, uma vez apedrejado, três vezes naufraguei... (2Cor 11,24-29). O Evangelho não é um discurso, mas uma experiência de fé, que assume o testemunho em todas as circunstâncias até às últimas conseqüências (Gl 2,20). Numa academia universitária, num centro filosófico de letrados e doutos, cabe o recurso da palavra, do discurso e da oratória, mas no caminho de Jesus, é preciso assumir o compromisso radical de fazer cegos ver, surdos ouvir, coxos andar e mortos ressuscitar (Lc 4,18-19). Só assim a cruz de Cristo se plenifica na missão do/a discípulo/a. Pode estar embutida uma crítica à falácia dos discursos políticos, da retórica rabínica, das diatribes filosóficas e outros esquemas da persuasão pela palavra.

Paulo não pretende diminuir o sentido ou a função de batizar, mas coloca duas atividades frente a frente e, ele mesmo afirma que evangelizar está em

${ }^{26}$ BAUER, W., Wörterbuch zum Neun Testament, Berlin/New York, Walter de Gruyter, 1971 
primeiro lugar. "Ele pretende sublinhar que o fato de batizar outras pessoas não o caracteriza como apóstolo". ${ }^{27} \mathrm{Na}$ práxis cristã o batismo é o momento sacramental, a evangelização é o tempo existencial. O momento sacramental tem hora e lugar para ser ministrado, enquanto que a evangelização não se caracteriza por um lugar e um momento no tempo, mas é todo o tempo, é o antes e o depois; o ontem, hoje e amanhã, é um processo de formação e solidificação na fé e no testemunho. A evangelização é a transformação permanente pela força do Espírito Santo: "Mas o Paráclito, o Espírito Santo que o Pai enviará em meu nome, vos ensinara tudo e vos recordará tudo o que vos disse" (Jo 14,26).

Evangelizar, para a Igreja, é levar a Boa Nova a todas as parcelas da humanidade, em qualquer meio e latitude, e converter a mentalidade, as intenções e as decisões pessoais e coletivas dos homens e mulheres que compõem as comunidades eclesiais ou ocupam cargos religiosos ou cívicos. É anunciar novos parâmetros familiares, novos caminhos econômicos através e pela pedagogia da "partilha do pão e da bênção do cálice eucarístico". É o pão do alimento partilhado à mesa, é o pão do salário partilhado na empresa, é o pão da justiça partilhado nas decisões, é o pão da verdade e sem camuflagens partilhado na elaboração de leis e princípios, é o pão da misericórdia partilhado com todos os excluídos da mesa do altar do mundo.

\section{Evangelizar ou batizar? 1Cor 1,14}

Paulo tem uma preocupação profunda com a evangelização. Ele fazia a distinção de batizar e evangelizar. Sem desprezar o batismo, mas com um certo desabafo pelos equívocos que a pastoral do batismo originara em Corinto, afirmava: "Dou graças a Deus por não ter batizado ninguém de vós, a não ser Crispo e Gaio" (1Cor 1,14). Depois, fazendo um pequeno balanço, viu que batizou mais alguém, que era a família de Estefanas (1Cor 1,16).

A sua preocupação é com o sistema continuado, com o método do anúncio, com as formas de apresentar, conscientizar e comprometer não apenas em

${ }^{27}$ BARBAGLIO, G. As cartas de Paulo, I, São Paulo, Loyola, 1969, p. 180. 
um momento, mas a vida toda dentro de um processo de compromisso e de profecia. Todo aquele que ouviu o anúncio deve dispor-se a ser apóstolo/a, não apenas um privilegiado ou um consumidor dos mistérios divinos. Por outro lado, em outra circunstância, que é a comunicação com a comunidade da Galácia, ele percebe a dificuldade de clareza na compreensão do Evangelho e, estranhamente, a presença de pessoas que anunciavam outras formas de Evangelho.

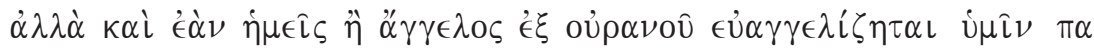

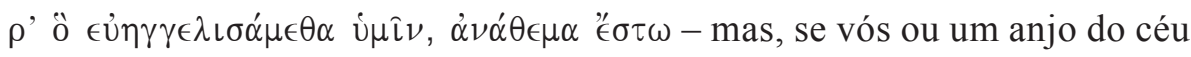
vos anunciar de lado (de outra forma) daquilo que vos anunciamos, seja maldito!" (G1 1,8).

"Tradição e Escritura constituem um único depósito sagrado da Palavra de Deus, confiado à Igreja. Acolhendo-o, o povo santo, unido a seus pastores, persevera na doutrina dos apóstolos, na comunhão, na fração do pão e nas ininterruptas orações (At 2,42)" ${ }^{28}$ Esse documento do Vaticano II (DV) entende que não pode haver dois anúncios, dois Cristos ou simulações da verdade e do Evangelho. O Evangelho segundo Nosso Senhor Jesus Cristo é um único, apenas formalizado e explicitado às diferentes regiões e culturas do modo mais adequado possível. Por isso temos quatro apresentações da mesma verdade e da mesma mensagem nos quatro Evangelhos canônicos. No entanto, para a comunidade da Galácia, Paulo é enfático: mesmo que um anjo baixado dos céus, um avatar ou qualquer indivíduo vos anunciasse algo de modo paralelo ou diferente do que vos anunciamos, seja anátema (G1 1,8).

Qual é o Evangelho que Paulo anuncia e que não pode ser diferente? Que Evangelho estariam anunciando os outros? E se um anjo anunciasse algo paralelo, ou seja, um pouco diferente, os Gálatas deveriam rejeitá-lo, amaldiçoando o anunciador. Por que Paulo é tão claro, ou tão convencido de que está certo daquilo que anuncia? Com muita probabilidade o fundamento desta tese paulina está na convicção da liberdade trazida por Jesus Cristo e da nova

${ }^{28} \mathrm{DV}, 10$. 
realidade que deve nortear a vida religiosa e social no mundo cristão: "Não há judeu nem grego, não há escravo nem livre, não há homem nem mulher, pois todos vós sois um só em Cristo Jesus" (G1 3,28).

Essas diferenças eram comuns e aceitas como "naturalmente" colocadas em âmbito geral, dentro da sinagoga. A idéia de igualdade entre homem e mulher ou judeu e pagão, não obstante presente na Tradição (Dt 10,17), não era uma muito clara, nem enfatizada no judaísmo. Pode-se tomar como exemplo, as próprias diferenças entre os homens, na série de orações matinais nas quais um homem judeu dava graças a Deus por não ter nascido pagão, escravo ou mulher. ${ }^{29}$

A liberdade é um fator inerente ao Evangelho, mas a responsabilidade é sua companheira inseparável. A Lei foi como um pedagogo, até Cristo (Gl 3,24), mas em Cristo veio a liberdade. No entanto, em que consistiria esse Evangelho "paralelo" na Galácia? Barbaglio afirma que se tratava de opositores, os quais pressionavam para que os gálatas fizessem a circuncisão e abraçassem a lei mosaica $(4,21 ; 6,12-13) .{ }^{30}$ Esse Evangelho diferente ou outro Evangelho, misturando tradições, saudosismos, patriotismos, cultura e crendices se torna um anti-Evangelho, um não-Evangelho. Desta forma, Paulo é radical: mesmo que fosse um anjo do céu, e aconselhasse fazer esses passos, ele seria um herege por que isso é contra o Evangelho, e não há outro (Gl 1,7). Aqui havia uma tensão entre as propostas do Evangelho de Jesus e as tendências tradicionais do mosaicismo. "A grande tendência expressa nas palavras de Paulo em Gl 1,6-9, era adotar uma forma de evangelizar dos judaizantes,

\footnotetext{
${ }^{29}$ PASTOR RAMOS, F., La libertad em la Carta a los Gálatas, estúdio exegéticoteológico, Madrid, Eapsa, 1977, p. 82, citando Talmud Menahot, 43b: "Se enseña que el Rabi Meir decía - el hombre está obligado a decir estas três bendiciones todos los días - que no me ha hecho gentil (goy), que no me ha hecho mujer, que no me ha hecho ignorante. El rabi Aha bar Jacob oyó a su hijo recitando la bendición de que no le había hecho ignorante y le dijo: - Todavia algo más. Y lê respondió el hijo: - Que bendición (falta)? - El padre dijo: - Que no me ha hecho esclavo. Eso es lo mismo que mujer. Ser esclavo es más despreciable"

${ }^{30}$ Cf. BARBAGLIO, G. "Gálatas”, As cartas de Paulo II, São Paulo, Loyola, 1991, p. 39.
} 
que seria anular o Evangelho de Cristo, uma vez que os gentios como os judeus que aderem ao Evangelho são salvos pela graça e não pelas obras da lei. Portanto a forma de evangelizar própria dos judaizantes infiltrados nas comunidades da Galácia, não serve para os gentios que estão fora do contexto das tradições judaicas. A missão de evangelizar grupos diferentes comporta uma adaptação a dois públicos diferentes. Os que não estavam sob a Lei, estão livres dela". ${ }^{31}$

As tradições do passado, os saudosismos e conservadorismos esvaziam de sentido a cruz de Cristo (cf.1Cor 1,17; Gl 5,11). Jesus afirma de modo categórico que aos antigos foi dito de um modo, mas agora os tempos são outros, e eu vos digo assim ... (Mt 5,21ss). Esse "outro" Evangelho, que não é Evangelho não é senão de perturbadores e fracos na fé (Rm 15,1). Se é para a liberdade que Cristo nos libertou, todo retorno ao passado é uma volta à escravidão $(\mathrm{Gl}$ 5,1). Desta forma, o que era a circuncisão para os cristãos de origem judaica, podem ser saudades para muitos cristãos, hoje, camufladas nos desejos de um retorno aos costumes medievais com rubricas, símbolos e formas vazias e ultrapassadas que não estão na pedagogia de Jesus, nem no anúncio dos primeiros cristãos. Assim como muitos judeus, de modo particular na Galácia, tentavam atrapalhar Paulo, exigindo a circuncisão de todos os que aderiam ao cristianismo, não faltam movimentos, dentro das comunidades cristãs, que se parecem com seitas alienantes e alienadoras a serviço de outro Evangelho, quem sabe, o Evangelho da satisfação própria, da promoção pessoal, do carisma ditatorial de um/a líder.

Evangelizar é também abandonar as coisas velhas, os arquétipos simbolizados pelo farisaísmo, pela dependência cultural ou pela dependência psicológica. É óbvio que sem abandonar coisas antigas, não se cria espaço para as coisas novas. E, pode-se perguntar: como poderia alguém ser evangelizado se é incapaz de abandonar seu passado? Sem abandonar uma condição anterior, não há como assumir a posterior. O conflito da Galácia era esse: relativizar a circuncisão. $\mathrm{O}$ apego às tradições era mais forte que o Evangelho, e este

\footnotetext{
${ }^{31}$ ARTUSO, V. "Desafios na evangelização dos Gálatas - estudo exegético-teológico de Gl 1,6-10”, Atualidade Teológica 22(2006), p.114.
} 
apego anula o Evangelho, transforma o anúncio em outra coisa que é antiEvangelho, pois não há outro Evangelho (Gl 1,7). Pai, mãe, filhos, etc, (Lc 14,26-27), representam os afetos, os apegos ou os bens familiares, bem como, as paranóias, as psicoses, as esquizofrenias, os tabus e pendengas oriundas da fase infantil ou pré-natal. E quem fica apegado à família está voltado para o passado e não vê, nem entende o presente, e não será capaz de dar as razões da própria esperança $(1 \mathrm{Pd} 3,15)$. Jamais haverá uma evangelização verdadeira se o nome, a doutrina, o reino, o mistério de Jesus de Nazaré, não forem anunciados. E, em cada nova fase da história humana nasce uma preocupação instigadora: quem enviar a anunciar o mistério de Jesus? Com que linguagem anunciar tal mistério? Como fazer para que ele ressoe e chegue a todos aqueles que hão de ouvi-lo? ${ }^{32}$ Ampliando essa reflexão, podemos buscar outro ensinamento de Paulo, na carta aos Romanos: "Todo aquele que invocar o Nome do Senhor, será salvo" (Rm 10,13).

Para poder invocar o Nome do Senhor, é preciso que alguém o anuncie, mas não pode confundir, distorcer ou desfazer o núcleo central e essencial da apresentação desse conteúdo, o qual não pode ser modificado, nem desvirtuado e nem deixado no silêncio. ${ }^{33}$ Trata-se de uma preocupação muito grande, de modo especial na preparação dos evangelizadores, a fim de que a mensagem chegue de modo correto e verdadeiro, de modo eficaz e com métodos eficientes, de modo verdadeiro e por caminhos retos, de modo construtivo e com o testemunho profético. O Nome de Jesus só poderá ser invocado, se o Evangelho for único e o evangelizador bem evangelizado, pois a exortação de Paulo é clara: "Como poderiam invocar aquele em quem não creram? E como poderiam crer naquele que não ouviram? E como poderiam ouvir sem pregador? E como podem pregar se não forem enviados? Conforme está escrito: Quão formosos os pés dos que anunciam boas notícias" (Rm 10,14-15). Ora, essas dificuldades todas e questionamentos são inerentes à qualificação dos evangelizadores. Paulo conhece bem o seu contexto, neste caso, mesmo

\footnotetext{
${ }^{32} \mathrm{Cf} . \mathrm{EN}, 22$.

${ }^{33} \mathrm{Cf}$. EN, 25.
} 
sem ter visitado Roma, deve ter tido informações desta cidade, e quando escreve, faz algumas ressalvas sobre os pregadores. Ele mostra uma relação intrínseca entre:

a) invocar $\rightarrow$ crer

b) $\quad$ crer $\rightarrow$ conhecer (ouvir falar)

c) conhecer (escutar) $\rightarrow$ pregar

Se alguém não conhece, não pode invocar, declarar ou testemunhar a respeito. ${ }^{34}$ Há uma complexidade de elementos envolvendo a dimensão missionária, catequética e formativa do anunciador. Assim como na Galácia (Gl 1,6-9), alguns saudosistas da circuncisão queriam voltar a Moisés e adaptar Jesus às tradições, não faltam, em todos os lugares e tempos falsos evangelizadores, que anunciam suas paranóias em lugar do Evangelho, impedindo que as comunidades conheçam o sentido, a forma e o conteúdo da evangelização. Quando isso acontece, Deus será buscado pelos de fora, pelos que têm falsos mensageiros, por que estes se constituem em desobedientes e rebeldes, estéreis e com frutos azedos, como denunciava Isaías (Is 5,2).

\section{A matemática do discipulado, Mt 13,4-23}

Evangelizar todas as nações é conduzir o Evangelho até elas e possibilitar que, depois de escutar, acreditem, acolham e testemunhem essa Boa Nova, tornando-se novos evangelizadores. A Boa Nova é a semente, mas ela precisa de um campo e de um semeador que a espalhe (Mt 13,4-23). A terra pode ser diferente, mas a semente é sempre boa. O semeador não pretende jogar fora a semente, nem desperdiçar seu tempo. A expectativa do semeador é de que toda a semente produza cem por cento em relação às próprias capacidades e condições.

$\mathrm{Na}$ missão confiada aos discípulos, todas as nações merecem ouvir falar de Jesus e ser evangelizadas, isto não implica apenas na mudança de ritos, mas

\footnotetext{
${ }^{34}$ MAZZAROLO, I, Carta de Paulo aos Romanos, educar para a maturidade e o amor, Rio de Janeiro, Mazzarolo editor, 2006, p.133.
} 
prioritariamente na prática da justiça (Mt 5,20). A missão é como uma conta de matemática: entre entradas e saídas, é preciso que haja um resultado positivo e cada um precisa empenhar tudo o que tem para fazer esse resultado ser o melhor possível. Na parábola dos talentos (Mt 25,14-29) cada um que recebeu uma porção do seu senhor, tem a missão de desenvolver e fazer produzir o que recebeu, pois isso corresponde às suas capacidades. Logo, se não produzir cem por cento do que recebeu, torna-se negligente e displicente com o seu senhor. A missão tem um imperativo quanto ao aumento dos evangelizados. A cada colheita deve haver um número maior de frutos. Toda a comunidade precisa crescer a cada ano e se não cresceu há um erro grave da parte de quem evangeliza.

Assim como no mundo econômico, no final de cada ano é feito um balanço dos resultados, na vida pastoral deveria haver o mesmo modo de fazer o balanço. A comunidade, juntamente com seu líder, necessita fazer essa soma e perguntar-se quantos novos cristãos somaram-se ao longo do ano. Se o número de novos adeptos for pequeno, há uma necessidade de rever os caminhos, meios e métodos usados no processo de anúncio, para verificar os não-acertos. Se o número for significativo, a pergunta poderia ser: por que não foi maior? Se o número é insignificante, o fracasso já está demonstrado. A metáfora da semente (Mt 13,4-23) e da videira (Jo 15,1-8) revelam um imperativo matemático qualitativo e quantitativo na missão, pois não havendo um aumento progressivo, não serão atingidos todos os povos e culturas. Para cada evangelizador está colocado o compromisso, a missão e o desafio de produzir. O verbo fazer (molé $\iota$ ) tem um uso privilegiado no Novo Testamento, com um destaque especial no ensinamento de Mateus 7,21: "Nem todo aquele que me diz Senhor, Senhor entrará no Reino dos Céus, mas aquele que faz a vontade

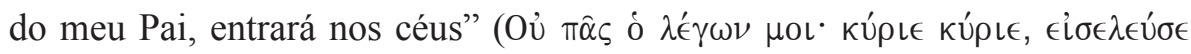

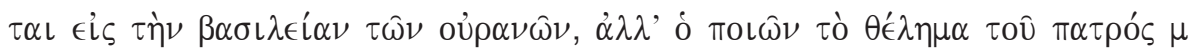

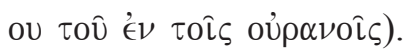

Jesus afirma aos discípulos que sem ele nada poderiam fazer (Jo 15,5). $\mathrm{O}$ verbo fazer indica produzir, desenvolver, gerar. No ensinamento sobre a 
forma de glorificar o Pai e de serem reconhecidos como discípulos, usa o verbo

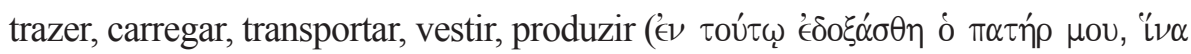

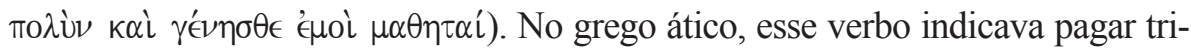
butos (carregar os tributos até o lugar do pagamento), no uso clássico e em Platão o verbo era usado para indicar produção, algo que cresce e se desenvolve como

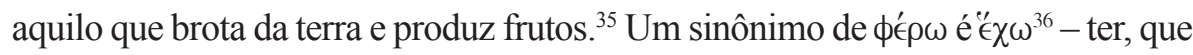
mostra a conseqüência da ação, pois só tem quem produz. Segundo esse ensinamento de Jo 15,1-8 a expectativa de frutos é a forma de glorificar o Pai. Caso não haja frutos, há um desprezo pela orientação, pelo mandamento do Pai transmitido pelo seu Filho. Desta forma, o Pai será manifesto na "produção" dos frutos do Reino que deverão estar nas obras dos filhos, ou seja, de modo patente naqueles que foram chamados e aceitaram trabalhar na sua vinha (cf. Mt 21,28-32). A metáfora dos frutos não pode ser considerada como uma pequena somatória de atitudes de piedade, de devocionismo ou alguns ritos espirituais, ainda que estes não possam ser desprezados, mas os frutos aqui são o crescimento e o aumento do rebanho, o Evangelho sendo anunciado a toda a criatura.

\section{Fazer discípulos é ter comunhão com o Mestre $^{37}$}

A fé precisa do auxílio da razão e os instrumentos científicos para ser melhor conhecida e mais amada. Sem o auxílio das ciências, é impossível conhecer profundamente o sentido e a finalidade das Escrituras.

"É ilusório pensar que, tendo pela frente uma razão débil, a fé goze de maior incidência; pelo contrário, cai no grave perigo de ser reduzida a

\footnotetext{
${ }^{35}$ BONAZZI, B., Dicionário greco-italiano, Nápoli, Alberto Morano editore, 1943.

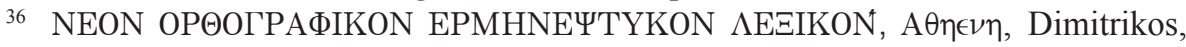
1969.

${ }^{37}$ MAZZAROLO, I. Evangelho de Marcos, estar ou não com Jesus, Rio de Janeiro, Mazzarolo editor, 2004, Nesta obra enfocamos de modo especial a dimensão da comunhão do discípulo com o Mestre, como o primeiro passo para a missão ou o envio. A primeira fase do discipulado é estar com Ele, depois receber autoridade e o envio (cf. esp. Pp. 103-127).
} 
um mito ou superstição. Da mesma maneira, uma razão que não tenha pela frente uma fé adulta não é estimulada a fixar o olhar sobre a novidade e a radicalidade do ser". ${ }^{38}$

A fé bíblica, auxiliada pela razão, fez a passagem dos mitos ao conhecimento da verdadeira imagem de Deus. "Nas culturas que circundam o mundo da Bíblia, a imagem de Deus e dos deuses permanece, tudo somado, pouco clara e, em si mesma, contraditória". 39 "A força divina que Aristóteles, no auge da filosofia grega, procurou individuar mediante a reflexão é, certamente, para cada ser, objeto do desejo e do amor - como realidade amada esta divindade move o mundo - mas ela mesma não necessita de nada e não ama, é amada somente". ${ }^{40}$ No entanto, esta confusão religiosa está mais presente onde a razão está mais distante. No mundo bíblico e de modo particular no Novo Testamento, a razão e a fé andam juntas em busca do conhecimento de Deus e do entendimento das profundidades do ser humano. Assim emerge uma nova consciência de Deus: Ele é Pai, é Criador, é Amor (Mt 7,6-13; Lc 11,2-4). Esse Deus amor enviou seu Filho para tornar explícito esse conhecimento ao mundo (Jo 1,17-18).

Com muitos gestos e palavras, o Filho deu ao mundo um conhecimento direto e explícito do Pai, de tal forma que Jesus reage indignado à pergunta de Filipe a fim de que lhe mostrasse o Pai: - "Quem me vê, vê o Pai!" (Jo 14,9). Esta imagem do Pai está clara no ato de amor de seu Filho que amou o mundo até o fim e até às últimas conseqüências em virtude de sua opção pelo serviço e libertação da humanidade (Mc 10,45). Diante desta oferta, "temos, agora, que prestar atenção a outro aspecto: a mística do sacramento tem um caráter social, porque, na comunhão sacramental, eu fico unido ao Senhor como todos os demais comungantes. A união com Cristo é, ao mesmo tempo, união com todos os que o acolheram (Jo 1,11-14). Eu não posso ter Cristo só para mim;

${ }^{38}$ JOÃO PAULO II, Fides et Ratio, 48; Cf. ESTUDOS DA CNBB, 86, Crescer na leitura bíblica, 84 .

${ }^{39}$ BENTO XVI, Deus catitas est, 9.

${ }^{40}$ BENTO XVI, Deus caritas est, 9. 
posso pertencer-lhe somente unido a todos aqueles que se tornaram ou se tornarão seus. A comunhão tira-me para fora de mim mesmo projetando-me para ele e, desse modo, também para a união com todos os cristãos". ${ }^{41}$

O trabalho de investigação, para quem ama e vive o que anuncia, não se encerra num curso de quatro anos de teologia, na leitura de alguns livros. "O que era verdade em 1943 ainda o é nos nossos dias, porque o progresso das investigações trouxe soluções para certos problemas e, ao mesmo tempo, novas questões a estudar. $\mathrm{Na}$ exegese, como em outras ciências, quanto mais se abrem as fronteiras do desconhecido, tanto mais se alarga o campo a explorar". ${ }^{42}$ É imperativo conhecer para anunciar, em virtude do desafio de tantas correntes fundamentalistas cuja visão do mundo e do ser humano é estreita e obtusa, sua compreensão e dimensão cósmica está em suportes ultrapassados. ${ }^{43}$

A XV Assembléia de Aparecida poderá traçar novos rumos na formação dos arautos da Palavra a fim de que tenham uma fé mais explícita, uma razão mais cósmica e uma bagagem, de História e arqueologia amplos e profundos para dialogar com o mundo, quer a nível pastoral, que nas esferas acadêmicas, científico-tecnológicas, anunciando, refutando e ensinando com toda a sabedoria, persistência e sã doutrina, sem ideologias, fanatismos e discussões estéreis manipuladas (cf. 1Tm 4,1-7; 2Tm 4,2). A conviç̧ão da missão, a certeza da fé e a clareza da razão fazem a diferença do profeta, do mensageiro e do arauto do Evangelho. É ilusão pensar que para alicerçar a palavra no meio de tantas ideologias, de correntes de pensamento tão dispersos, de teorias errôneas sobre a vida, sobre o ser humano, de tantos ditos sobre o endeusamento da moda, do estilo, dos modelos "bio-tipo", das ideologias subjacentes nas telenovelas, baste um pouco de piedade devocional. Faz-se necessário conhecer profundamente, primeiro,

\footnotetext{
${ }^{41}$ BENTO XVI, Deus caritas est, 14.

${ }^{42}$ PONTIFÍCIA COMISSÃO BÍBLICA, A interpretação da Bíblia na Igreja, pp. 19-20.

${ }^{43}$ PONTIFÍCIA COMISSÃO BÍBLICA, A interpretação da Bíblia na Igreja, p.84.
} 
para depois anunciar, denunciar e refutar. Esta V Assembléia de Aparecida deverá pensar na formação e na competência dos evangelizadores/as.

\section{Evangelizar é edificar a Igreja}

Na Igreja de Corinto havia anunciadores que, por ingenuidade ou por inveja, confundiam o anúncio de Jesus Cristo com o seu próprio anúncio, a tal ponto que os grupos e partidos dividiram a comunidade, ora por simpatia a um pregador, ora por rivalidade e hostilidade ao outro (cf. 1Cor 1-4). Não raro, a falsa idéia de evangelização, a má formação dos evangelizadores, em lugar de construir, destrói a Igreja local ou diocesana. Muitos acreditam que falando línguas estão mais próximos de Deus - mera banalidade (cf. 1Cor 14,4). Outros acreditam que alcançam Deus pela força dos gritos e palavrório (Mt 6,7). Difícil é a consciência da construção da Igreja, da edificação de um edifício humano, da transformação do próprio corpo, inteligência, vontade e condições numa oferenda de si próprios como resgate e num culto agradável ao Senhor e aos irmãos (Rm 12,1-2).

Quando alguém busca a comunidade para satisfazer suas necessidades, torna-se um parasita e necessita ser corrigido (cf. 1Ts 5,14-15), assim como quem fala em línguas, edifica a si mesmo porque não expressa nesse falar a caridade e a presença do Espírito. Edificar é trabalhar em conjunto, é entendimento e sintonia. A unidade na diversidade faz a obra de Deus (1Cor 12,1226), mas tudo deve colaborar para o $\dot{\alpha} \gamma \alpha \dot{\pi} \pi \eta$ (amor). Essa consciência coletiva, integradora, sólida e evangélica, faz o bem da comunidade e a edificação do Corpo místico de Cristo (Cl 1,15-20).

\section{Evangelizar é aprender das primeiras comunidades}

Aprender das primeiras comunidades é refletir a palavra e aplicar o resultado da reflexão de tal forma que possam aparecer frutos constantes e sempre novos. Refletindo a palavra e partilhando o pão, os cristãos são convidados a formar novas comunidades eclesiais, com espírito novo e forças renovadas, 
atualizando, inculturando e inserindo, nos mais diversos meios e lugares a mensagem do Evangelho. Para tanto, uma preparação intelectual, uma formação moral e maturidade afetivo-espiritual se fazem imprescindíveis. Sem sombra de dúvida, as orientações dadas às Comunidades Eclesiais de Base servem, indiscutivelmente, aos líderes, aos anunciadores e a todos aqueles que se dispõem a assumir o chamado da evangelização. ${ }^{44}$

Evangelizadores e Igrejas atuais necessitam imperiosamente buscar luz e espiritualidade nos exemplos primevos do cristianismo. A humildade, a virtude, a caridade e o amor não podem ser suplantados pelasexpressões de hipocrisia e fingimento (cf. Rm 12,9). "Na Igreja católica e noutras Igrejas e Comunidades Eclesiais, também aparecem novas formas de atividade caritativa e ressurgiram antigas, com zelo renovado. São formas nas quais se consegue, muitas vezes, estabelecer uma feliz ligação entre evangelização e obras de caridade" ${ }^{45} \mathrm{O}$ vigor espiritual e intelectual dos agentes da evangelização poderá ser um fator decisivo para novos paradigmas da evangelização atual na Igreja católica, após a V Assembléia de Aparecida.

O que é desejável e saudável para a Igreja, depois de Aparecida, é que encontre novos paradigmas para a formação de seus agentes e eles se empenhem mais com sua responsabilidade na missão de Cristo, tenham consciência de que, mesmo enviados como cordeiros no meio de lobos (Lc 10,3), em suas vidas está a importância na construção do amor solidário, fraterno e diaconal (Jo 13,35).

Evangelizar é agir sob a unção do Espírito do Senhor. Jesus sentia-se ungido pelo Espírito do Senhor, e por isso sua missão se distinguia de ou-

\footnotetext{
${ }^{44}$ Cf. EN, 58: As linhas centrais das orientações: As CEBs serão: a) o lugar da Evangelização; b) busquem seu alimento na Palavra de Deus; c) evitem a tentação da contestação sistemática; d) permaneçam firmemente ligadas à Igreja local; e) mantenham comunhão sincera com os Pastores; f) jamais se considerem como destinatário único ou como agente único da evangelização; g) progridam cada dia na consciência do dever missionário e no zelo; h) demonstrem-se, em tudo, universalistas e nunca sectárias.

${ }^{45}$ BENTO XVI, Deus caritas est, 30.
} 
tros pregadores, sua doutrina era diferente, como quem tinha autoridade (Mc 1,27). Jesus convidou seus discípulos para estar com Ele e aprender d'Ele a pregar, curar e expulsar demônios (Mc 3,13-15). Era esse Espírito que o ungia para evangelizar os pobres, para curar todas as enfermidades e libertar os presos (cf. Lc 4,18-19; Is 61,1-2). Aquilo que ele contemplou junto do Pai, testemunhou ao mundo e o mundo reconheceu que tudo o que anunciou vinha do Pai (Jo 17,6-8).

Os primeiros cristãos, seguindo muito de perto as pegadas do Mestre, numa relação muito íntima do discipulado (mestre-discípulo - Lc 6,40; Jo 13,16), anunciavam ao mundo de seu tempo, o Evangelho da experiência, da comunhão e do entendimento: O que era desde o princípio, o que ouvimos, vimos, contemplamos, o que tocamos com nossas mãos, - o Verbo da vida, este nós vimos e damos testemunho, pois esta é a Vida eterna (1Jo 1,1-2). Esta comunhão com o Deus da vida e do amor, fazia dos primeiros cristãos arautos da verdade, do amor, da solidariedade e do perdão, não apenas aos da casa, conhecidos, mas também aos inimigos (Lc 6,27-35).

Retornando ao ponto de partida (Mt 28,19), entendemos que o primeiro passo para evangelizar é deixar-se evangelizar, colocar-se aos pés do Mestre como Maria (Lc 10,39) e ouvir tudo o que Ele tem para ensinar e, depois, sabendo o que Ele quer, fazer tudo o que for determinado. Essa evangelização da parte do Mestre, transforma o verdadeiro discípulo num Theófilo ( $\operatorname{Lc} 1,3$; At 1,1 ) ou num discípulo amado (Jo 13,23; 19,26; 21,7.20) ${ }^{46}$

\section{Conclusões}

Essa V Assembléia da Igreja Latino-Americana, de alcance Continental, em Aparecida, 2007, não poderá furtar-se a uma grande reflexão sobre os

\footnotetext{
${ }^{46}$ Cf. MAZZAROLO, I, Lucas em João, uma nova leitura dos Evangelhos, Rio de Janeiro, Mazzarolo editor, 2004, pp. 60-66: Nestas páginas trabalhamos o possível paralelismo entre o Teófilo de Lucas e o Discípulo amado de João, visto que os dois são discípulos que estão no lugar certo, na hora certa.
} 
caminhos da Igreja atual em meio a um emaranhado de seitas, correntes de pensamento e conflitos externos e internos, à semelhança de Corinto nos primeiros tempos do cristianismo. Espera-se que a assistência do Espírito Santo, sobre todos e cada um, inspire decisões proféticas e sábias para delinear novas rotas, quer na formação de agentes de evangelização, quer no estabelecimento de linhas pastorais mais ousadas e mais bíblicas, à luz do Evangelho e do testemunho dos primeiros cristãos.

Espera-se que as luzes do mesmo Espírito encaminhem os passos destes Pastores e teólogos para um "kairós" e sejam tomadas decisões sábias para os próximos anos. Que a refontização, na interpretação da Escritura, seja uma marca nítida, como postulava o Vaticano II:

"A Sagrada Escritura deve ser lida e interpretada no mesmo Espírito com que foi escrita, para entender corretamente o sentido dos textos sagrados não se pode desprezar o conteúdo e a unidade de toda a Escritura, nem deixar de levar em conta a Tradição viva de toda a Igreja e a analogia da fé" (DV, 12). E, à luz do mesmo Pentecostes (At 2,1-11), que inundou o grupo trancado em casa por medo dos judeus (Jo 20,19), as Igrejas e seus pastores sejam encorajados a reconstruir o sentido das comunidades primitivas que eram os pequenos grupos, reunidos em casas de família, seguindo muito de perto o exemplo de Jesus, que ensinava, curava e evangelizava nas casas ou próximo delas nas suas, praças, campos e cidades. ${ }^{47}$

As Faculdades eclesiásticas "promovam com empenho as ciências sagradas, recorrendo aos métodos e recursos mais recentes para desenvolver a pesquisa de maneira cada vez mais profunda e ampla" (GE, 11).

\footnotetext{
${ }^{47}$ SCERRA, Lucia, Le picole bibliche: il nuovo volto della volontà di Dio nella chiesa del Terzo Millennio, Bogotá, Pontí́cia Universidad Javeriana, 2006, p. 132. A autora argumenta, de modo claro e objetivo a estrutura das primeiras comunidades e faz uma comparação entre as mesmas e o espírito eclesial que fez surgir as CEBs, na América Latina e particularmente no Brasil. As CEBs, como pequenas Igrejas, unidas a uma coordenação maior, formavam núcleos de Igrejas domésticos à semelhança das primeiras comunidades cristãs.
} 
São Jerônimo afirmava que ignorar as Escrituras era ignorar Cristo ${ }^{48}$. Poderíamos parafrasear Jerônimo, dizendo: Ignorar a missão é desconhecer o discipulado; ignorar a missão é ignorar o Evangelho. A dimensão sacramental, hoje, parece ter obnubilado a evangelização. A responsabilidade de sair de casa, ir ao encontro dos não-crentes e dos crentes que se perderam, daqueles que foram batizados e não retornaram mais ao redil, parece mais urgente que nunca.

E, além de uma nova impostação do discipulado, faz-se necessária uma nova configuração dos manuais de catequese, novos conceitos e parâmetros na formação dos catequistas, e nova consciência eclesial. Não há Evangelho fora da missão e não há missão sem novos conceitos de evangelizadores, formadores de opinião. Acrescente-se, outrossim, novos conceitos de comunidades eclesiais e novo conceito de Eucaristia.

\section{Résumé}

L'évangélisation a besoin de la mission, de l'envoi et de l'annonce. La réunion de l'É piscopat Latino-americain à Aparecida, en 2007, devra se débrousser sur la source première du christianisme qu'est l'évangélisation, aujourd'hui, en manque et déficitaire. Les lignes herméneutiques bibliques pour ces peuples sont un ressourcement de son essence, un retour aux origines et une reprise de la mission, sous le risque de vider le sens de l'Évangile.

Isidoro Mazzarolo PHD pela École Biblique et Archéologique de Jerusalém Professor do Dept. ${ }^{\circ}$ de Teologia da PUC-Rio

48. Cf. DV, 25. 